\title{
MUDANCCA ESTRUTURAL DOS CONTRAPÚBLICOS EM FACE A CONTROVÉRSIAS ARTÍSTICO-CULTURAIS
}

The structural transformation of the counterpublics before artistic and cultural controversies La transformación estructural de los contrapúblicos ante las controversias artístico-culturales

$>$ Cayo Honorato [Universidade de Brasilia, Brasil]* Diogo de Moraes Silva [Universidade de São Paulo, Brasil]* *

RESUMO Nos últimos anos, manifestações contrárias às artes questionaram uma suposta receptividade dos públicos. O fato de os detratores compartilharem várias características dos contrapúblicos suspendeu a vinculação exclusiva do termo aos públicos progressistas. Mas a mudança não se reduz a uma ampliação de escopo do conceito; ela vai da ascensão de ultraconservadores à disjunção entre as instâncias normativa e descritiva que o conceito era capaz de sobrepor. Após revisarmos a teoria de Michael Warner sobre os contrapúblicos, discutimos os usos do termo pelo campo da arte, para então confrontá-los com duas expressões daquela mudança: o caso Queermusev e a formação de um contrapúblico ultraliberal.

PALAVRAS-CHAVE contrapúblicos, esfera pública, Michael Warner, Queermuseu, guerras culturais

ABSTRACT In recent years, demonstrations against the arts have questioned the supposed receptivity of the audience. The fact that detractors share several characteristics of the counterpublics suspended the term's exclusive link to progressive audiences. But the change has not just expanded the scope of the concept; it ranges from the rise of ultraconservatives to the disjunction between the normative and descriptive instances which the concept was able to conflate. After reviewing Michael Warner's theory about counterpublics, we discuss the uses of the term in the field of art, and so confront them with two expressions of that change: the Queermuseu case and the formation of an ultraliberal counterpublic.

KEYWORDS counterpublics, Michael Warner, public sphere, Queermuseu, culture wars

* Cayo Honorato é Doutor em Educação e Professor Adjunto pela Universidade de Brasilia. E-mail: cayohonorato@unb.br, ORCID: hitps://orcid.org/0000-0002-5220-0691
* * Diogo de Moraes Silva é Doutorando em Artes Visuais pela Universidade de São Paulo. E-mail: diogodemoraes@gmail.com, ORCID: htrps://orcid.org/0000-0001-5124-1355 
RESUMEN En los últimos años, las manifestaciones contra las artes han cuestionado la supuesta receptividad de los públicos. El hecho de que los detractores compartan varias características de los contrapúblicos ha suspendido el vínculo exclusivo del término con los públicos progresistas. Pero el cambio no se trata solo de ampliar el alcance del concepto; va desde la ascensión de los ultraconservadores a la disyunción entre las instancias normativas y descriptivas que el concepto supo superponer. Después de revisar la teoría de Michael Warner sobre los contrapúblicos, discutimos los usos del término por parte del campo del arte, para luego confrontarlos con dos expresiones de ese cambio: el caso Queermuseu y la formación de un contrapúblico ultraliberal. PALABRAS CLAVE contrapúblicos, esfera pública, Michael Warner, Queermuseu, guerras culturales

(Submetido: 10/12/2020;

Aceito: $13 / 5 / 2021$;

Publicado: 7/7/2021)

Citação recomendada: HONORATO, Caio; SILVA, Diogo de Moraes. Mudança estrutural dos contrapúblicos em face a controvérsias artístico-culturais. Revista Poiésis, Niterói, v. 22, n. 38, p. 309-343, jul./ dez 2021. [https://doi. org/10.22409/poiesis. v22i38.47572]. Este documento é distribuído nos termos da licença Creative Commons Atribuição-NãoComercial 4.0 Internacional [CC-BY-NC] (C) 2021 Caio Honorato e Diogo de Moraes Silva. 
INTRODUÇÃO

Tributário da sociedade burguesa, o conceito de esfera pública remonta ao século XVIII e designa originalmente o caráter aberto do debate de ideias em torno de preocupações comuns, fomentado pela imprensa e pela cultura do livro. Desenvolvendo-se fora do domínio do Estado, esse debate, em tese, é acessível a um público irrestrito de pessoas privadas, processando-se em contraposição ao poder estatal, mediante argumentação crítico-racional [REPA, 2005]. Essa vocação tem por pressupostos a igualdade, a liberdade, a publicidade e a inclusão universais, que municiam a sociedade civil burguesa na busca pela transformação da ordem dominante no Antigo Regime. A principal referência no assunto é o filósofo Jürgen Habermas [2014 [1962]], para quem o advento do Estado social de direito, a partir das últimas décadas do século XIX, associado à crescente massificação das experiências cultural e comunicativa, provocou o que ele chama de uma "mudança estrutural da esfera pública".

O presente artigo parafraseia essa mudança, chamando atenção para sua incidência relativa a uma figura marginal da esfera pública: o contrapúblico, em suas diferentes personificações e irrupções. se o bem-estar social, os meios de comunicação em massa e a indústria cultural produziram alterações profundas na lógica e no funcionamento da esfera pública - tendo em vista a desarticulação de sua função crítica pelos imperativos do consumo cultural e informacional, associados à promiscuidade que se estabelece nesse processo entre Estado e sociedade -, por outro lado, os contrapúblicos parecem ter trilhado caminhos heteróclitos, cruzando obliquamente os padrões e prerrogativas da esfera pública. Logo, a mudança estrutural a que nos referimos não necessariamente acompanha as mesmas transformações sofridas pelo ambiente discursivo em que os contrapúblicos são personagens de exceção.

Embora o surgimento dos contrapúblicos seja concomitante ao dos públicos crítico-racionais da esfera pública, eles emergem em reação a supostos consensos sociais de maneira notadamente descontínua e imprevista - o que tende a Ihes atribuir um caráter duplamente progressista. Acompanhando, porém, algumas de suas manifestações mais recentes, particularmente em relação ao campo das artes, verificamos que a contrapublicidade [counterpublicness] vem sofrendo mudanças que solicitam uma revisão de seu progressismo. Nesse sentido, é também nossa compreensão acerca dos contrapúblicos que deve mudar, de modo a considerar a heterogeneidade de seus pleitos e 
performances nos lugares em que os discursos públicos se entrecruzam e se referenciam. Na seção seguinte, buscamos discutir detalhadamente o entendimento de Michael Warner sobre o conceito. A revisão um pouco extensa se justifica por duas razões: o autor ainda não foi suficientemente traduzido para o português ${ }^{1}$ e, como iremos demonstrar, uma interpretação parcial de suas ideias tem sido recorrente em diferentes campos.

\section{OS CONTRAPÚBLICOS SEGUNDO MICHAEL WARNER}

Embora reconheça que Habermas jamais adotou uma concepção unitária de público, ou ainda, que sua reflexão sempre enfatizou diferentes tipos de discurso público, das conversas de bar à crítica de arte, Michael Warner [2005] entende que o filósofo terminou confundindo, em seu livro Teoria do agir comunicativo [1981], o exercício da razão pública com a argumentação tête-à-tête. Assim, acabou desconsiderando o que de certo modo havia reconhecido no Mudança estrutural da esfera pública [1962]: que o público corresponde tanto a um modo de endereçamento quanto a uma audiência indeterminada. Mas o que Habermas principalmente ignorou foi que alguns públicos são definidos por sua tensão com um público mais amplo, pelo conflito com as normas de seu próprio ambiente cultural - o que para Warner representa uma primeira característica dos contrapúblicos.

Segundo o autor, os contrapúblicos são públicos que têm alguma consciência de seu status marginal e subordinado; que se organizam por "disposições ou protocolos alternativos"; que se mostram abertos às dimensões poéticas, afetivas e expressivas da linguagem; que "se definem por meio de [...] performances tipicamente corporificadas" [WARNER, 2005, p. 103]. ${ }^{2}$ Inicialmente, seus exemplos são o movimento feminista, as culturas gay e lésbica, e o discurso afeminado [WARNER, 2005, p. 55-63]. No entanto, porque tais exemplos são frequentemente associados a uma subcultura, sua relação com o sentido de contrapúblicos precisa ser mais bem esclarecida. Para Warner, os termos não se recobrem inteiramente. Nesta seção, revisaremos tanto a relação dos contrapúblicos aos conceitos de esfera pública [em sentido habermasiano] e público discursivo [em sentido warneriano], quanto às diferenças "internas" entre os diferentes tipos de contrapúblicos, notadamente, entre os contrapúblicos subalternos e os contrapúblicos performativos e, depois, entre contrapúblicos progressistas e conservadores. Entre esses conceitos e posições, há tanto diferenças quanto pontos em comum, de modo que os binarismos aqui perdem qualquer utilidade. 
Assim como os públicos da esfera pública, os contrapúblicos possibilitam um horizonte de opinião e troca, relacionam-se criticamente com o poder, têm uma extensão indefinida, são mediados pela imprensa, entre outros meios e redes mais difusas. No entanto, ao contrário dos públicos, são frequentemente pensados como subalternos. ${ }^{3}$ Warner esclarece que nem todos os contrapúblicos podem ser caracterizados dessa forma.

Os exemplos a que ele recorre para demonstrá-lo são alguns públicos juvenis ou artísticos que operam como contrapúblicos, mas não são exatamente subalternos. Isso significa que os contrapúblicos não necessariamente representam identidades subalternas em sentido substantivo, que estariam constituídas previamente. Eles são entidades performativas. Sua participação no discurso público, no tempo em que ela se dá, é essencial à sua caracterização como tal. Por meio dela, sua "identidade" se forma e se transforma [WARNER, 2005, p. 56-7].
Um exemplo dessa performatividade transformadora é a Casa Susanna, um clube de drag queens que, entre os anos 1950 e 60, se reunia em uma casa em Nova Jersey. ${ }^{4}$ Nesse ambiente doméstico, o contexto privado é subvertido pela ambição de "um tipo diferente de publicidade". O lugar corresponde a um espaço protopúblico de "improvisação coletiva”, no qual a transformação identitária parece depender

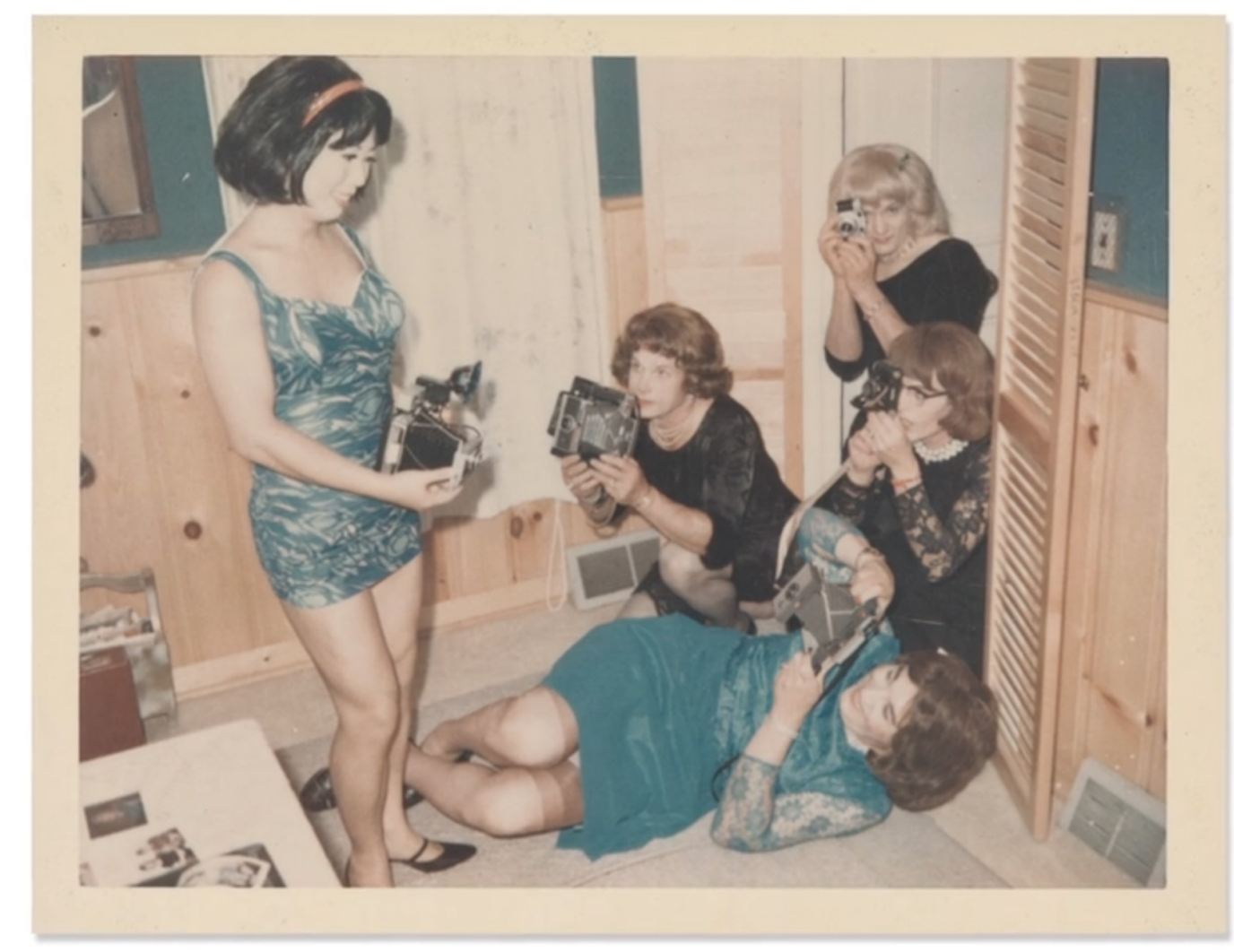

Fig. 1: Camera Club, Nova Jersey, 1962.

Fonte: SWOPE, Robert, HURST, Michael. Casa Susanna, 2005. 
de uma relação com outros públicos. Em uma de suas sessões de glamourização [fig. 1], as habitués da Casa posam umas para as outras, cada qual empunhando uma câmera fotográfica. A imagem ilustra a capa do livro Publics and Counterpublics. As câmeras sugerem que a cena pode ser vista por um sem número de estranhos, inclusive por quem as veria como "monstros do descaramento". Desse modo, forjam um ambiente simultaneamente íntimo e público, no qual as retratadas experimentam seus corpos de um modo que não seria possível sem aquele "testemunho". Assim, questionam o próprio sentido do que é público [WARNER, 2005, p. 13-4].

Em substituição aos públicos da esfera pública, Warner propõe o conceito de "públicos discursivos", 5 dos quais os contrapúblicos se diferenciam, mas sem deixar de compartilhar algumas características. Mais do que constatar, representar e veicular identidades ou interesses prévios, ambos constituem, performam e medeiam identidades ou interesses na esfera pública. Nesse sentido, a circularidade entre públicos e discurso também é essencial aos contrapúblicos. ${ }^{6}$ Diferentemente dos públicos, no entanto, os contrapúblicos elaboram "novas formas de cidadania [...] no sentido de uma participação ativa na construção de um mundo coletivo por meio dos públicos de sexo e gênero" [WARNER, 2005, p. 57]. Assim, transformam o lugar estigmatizado de suas vidas "privadas", de um modo que os diferencia dos públicos da esfera pública. Enquanto estes públicos supostamente constituem suas identidades no âmbito privado e debatem questões comuns de maneira crítico-racional, a partir da colocação entre parênteses de seus interesses pessoais, domésticos e familiares, os contrapúblicos constituem suas "identidades" em público.

Ainda segundo Warner, essa compreensão da performatividade dos contrapúblicos é responsável pela reabilitação de Hannah Arendt no âmbito da crítica feminista, para quem a filósofa representava um pensamento "masculino", que aparentemente ignorava a reivindicação do pessoal como político. Para Arendt, a vida política consistiria na modelação pública de um mundo em comum - o que não significa pôr de lado a individualidade e a privacidade, nem simplesmente estendê-las ao mundo público, mas sim abri-las a um processo de transformação por meio daquela modelação, onde as diferentes individualidades atuam umas sobre as outras, nas melhores situações, agonisticamente. Arendt nesse momento se opõe ao totalitarismo tanto quanto ao liberalismo. Certamente, o exercício daquela modelação pública também é limitado pelas assimetrias da sociedade massificada. Para Warner, no entanto, o movimento feminista e a cultura queer representam modelos típicos desse 
processo. Em vez de se comportarem como se a sociedade fosse uma extensão da família ou da vizinhança, eles parecem dispostos a elaborar mundos em comum e se transformar nesse processo, a partir do intercâmbio de pontos de vista com estranhos, questionando o caráter excludente das normas de participação num determinado contexto [WARNER, 2005, p. 58-61].

A par da necessidade de se entender concretamente as condições que medeiam o trabalho transformativo dos contrapúblicos, Warner conclui que, ao elaborar cenas coletivas para que as pessoas "saiam do armário", os contrapúblicos de gênero e sexualidade elaboram novas privacidades, corpos, cidadanias - que não guardam relação com a casa, o matrimônio, o parentesco, a propriedade, a nação [WARNER, 2005, p. 49-50, 116 e 199]. Nesse processo, podem certamente provocar "reações viscerais", inclusive porque a visceralidade, enquanto corporalidade expressiva, é uma das manifestações que eles buscam tornar publicamente relevante. Essas provocações também evidenciam contradições presentes na insistência em se manter uma oposição absoluta entre intimidade e publicidade [no sentido de publicness], quando a orientação para estranhos, mesmo em nossas atividades mais íntimas, é uma das dimensões mais significativas do imaginário moderno [WARNER, 2005, p. 76 e 200-1].
Após ser discutido no fim do capítulo Public and Private, o tema será retomado nas duas últimas seções do capítulo Publics and Counterpublics, no momento em que Warner avalia a relação do clube She-Romps ao periódico The Spectator. "trata-se de uma cena onde um grupo dominado pretende recriar-se como público, mas que, ao fazê-lo, entra em conflito não só com o grupo social dominante, mas com as normas que constituem a cultura dominante como público" [WARNER, 2005, p. 112]. É preciso aqui apresentar minimamente cada um dos atores envolvidos - o que faremos a seguir. Portanto, mais do que uma oposição a grupos ideologicamente distintos, os contrapúblicos se caracterizam pelo questionamento das normas que possibilitam a existência de públicos dominados e dominantes. Segundo Warner [2005, p. 112-3], "porque elas [cenas como a do She-Romps] diferem marcadamente [...] das premissas que permitem à cultura dominante se entender como público, elas passaram a ser chamadas de contrapúblicos".

The Spectatorfoi um jornal diário, publicado em Londres entre 1711 e 1712, no qual leitores [reais ou fictícios] publicavam suas opiniões sobre assuntos diversos: gosto, moda, maneiras, relações de gênero etc. Ao discutir questões privadas por meio de procedimentos impessoais, o periódico não só conferia relevância pública a essas questões, como 
atribuía a seus participantes um tipo de generalidade que até então era privilégio do Estado ou da Igreja. Trata-se de um dos primeiros periódicos a desenvolver uma "reflexividade sobre sua própria circulação", ao coordenar relações entre diferentes leitores, resultando na produção de um "público geral". Essa impessoalidade, no entanto, embora se dirigisse a qualquer um, reivindicando ser a voz da sociedade civil, representava um contexto de recepção prioritariamente masculino. De fato, uma série de requisitos materiais, linguísticos e sociais condicionam sua circulação entre estranhos. Se, por um lado, isso contradiz os postulados de uma circulação indefinida, reforçando a ideia de uma apropriação particular, por outro, não evita que outros públicos se imiscuam naquele contexto masculino [WARNER, 2005, p. 98-108].

Segundo Warner, uma tensão intrínseca ao discurso público - entre abertura e fechamento - impede que suas estratégias de dominação, no sentido de postular um público como sendo o público, sejam completamente bem-sucedidas. Tais estratégias são contudo visíveis, na forma como o periódico, a fim de assegurar sua legitimidade, representa cenas à margem de seu próprio público. É nesse contexto que a carta de uma das She-Rompsé publicada no no 217 do Spectator. Suas integrantes se encontravam à noite, uma vez por semana, num quarto alugado para esse propósito. Nesses encontros se despiam da discrição com que ser mulher Ihes obrigava a se comportar em público. Podiam ser rudes como homens, jogar fora as amarras do decoro, arrancar as roupas umas das outras. Mas o espaço que o Spectator lhes reserva não significa que ele as tem como público, muito menos que aprove seu estilo de sociabilidade, considerado demasiadamente corporal, agressivo e sexualizado. Entre o público feminino, o periódico espera no máximo inspirar conversas à mesa de chá, que não questionassem seu modelo de sociabilidade polida. Segundo Warner [2005, p. 111], "é a recusa de quaisquer normas familiares para a sociabilidade entre estranhos, mais do que a feminilidade, que faz delas uma contraimagem dos públicos".

Ao mesmo tempo, os contrapúblicos não estão imunes às críticas que fazem aos públicos dominantes. Afinal, também são públicos; trabalham com os mesmos postulados de circulação e circularidade, formam-se através da mesma sociabilidade entre estranhos - o que também significa que eles compartilham das mesmas contradições presentes na organização dos públicos, relativas às exclusões que praticam e suas limitações ideológicas. Para Warner, por exemplo, os contrapúblicos podem providenciar um sentido de "pertencimento" que mascara o fato de que eles não teriam um poder de atuação muito 
decisivo na sociedade capitalista. Em todo caso, esse imaginário do endereçamento público é estabelecido por meio de uma ética do estranhamento e uma poética do social, que de algum modo transformam tanto o Spectator quanto o She-Romps. Ao projetar a circulação entre estranhos como uma entidade social endereçável, o discurso público põe em risco o próprio mundo concreto que o sustenta, uma vez que esse mundo pode não ser completamente confirmado por aquela entidade. Essa estrutura contraditória não só determina sua instabilidade formal, como abre espaço para eventuais estranhamentos e reconfigurações [WARNER, 2005, p. 113].

Certamente, o fato de os contrapúblicos serem mais abertamente orientados para as dimensões poético-expressivas da linguagem é constantemente apagado pelo que Warner chama de uma "ideologia da linguagem". Essa ideologia caracteriza o discurso público enquanto diálogo entre interlocutores previamente constituídos, assim como a circulação enquanto espaço de deliberação crítico-racional. Seus pré-requisitos e protocolos discursivos possibilitam a confiança moderna na sociabilidade entre estranhos, característica da circulação pública. Porém, ela deriva, segundo Warner, de uma questionável transposição das faculdades do leitor privado para um horizonte geral de opinião pública, cuja capacidade de oposição ao poder estatal tem na racionalidade crítica sua principal avalista. No caso dos contrapúblicos, em função da sua expressividade e corporalidade, essa transposição não goza da mesma credibilidade. Sendo assim, uma vez estabelecidos os pressupostos da "opinião pública", todos os públicos tendem a ser assimilados como parte do público, no sentido de um espaço unitário [WARNER, 2005, p. 115-7].

Mas a univocidade do público, como dissemos, depende de uma série de protocolos para delimitar sua extensão potencialmente infinita. Os públicos que dominam tais protocolos terminam representando mais do que outros aquilo que consideramos o público. Certamente, muitos desses públicos não se veem como a nação nem como a humanidade; são públicos especializados, profissionais ou locais, que participam do público em geral e até podem se considerar seus membros mais representativos. Porém, alguns públicos se distinguem inegavelmente do público em geral. Neste ponto, Warner se refere à caracterização dos "contrapúblicos subalternos" por Nancy Fraser, para quem eles constituem "arenas discursivas paralelas onde membros de grupos sociais subordinados inventam e circulam contradiscursos, que por sua vez Ihes possibilitam formular interpretações de suas identidades, interesses e necessidades em sentido opositor" [FRASER, 1990, p. 67; FRASER apudWARNER, 2005, p. 118]. Fraser 
dá como exemplo o contrapúblico feminista do fim do século XX, com suas revistas, livrarias, editoras, redes de distribuição, centros de pesquisa etc. Mas o que faz desse público um contrapúblico?

Para Warner, a filósofa entende que os públicos não são unitários, mas os descreve de modo semeIhante a Habermas, como sendo crítico-racionais. Além disso, ela os descreve com base em suas identidades, desreconhecendo tanto sua dimensão performativa quanto sua dimensão poético-expressiva. Por sua vez, Warner entende que o caráter opositor dos contrapúblicos não pode ser uma função apenas de seu conteúdo. Fosse o caso, sua diferença para os públicos especializados se resumiria a um programa político particular. Ambos seguiriam os mesmos protocolos crítico-racionais, com a "diferença" de que os contrapúblicos teriam um caráter opositor. Além disso, Warner pergunta por que deveriam estar limitados a públicos "subalternos". Ou ainda, de que modo se diferenciariam dos fundamentalistas cristãos, por exemplo. Afinal, estes públicos também formulam interpretações opositoras de suas identidades, organizam-se por protocolos diferentes daqueles praticados noutros lugares, tiram diferentes conclusões a respeito do que pode ou não ser dito. Ainda se referindo aos fundamentalistas cristãos, Warner afirma que "tais públicos são de fato contrapúblicos, em um sentido mais forte do que aquele abrangendo subalternos com um programa reformista" [WARNER, 2005, p. 119, grifo nosso].

A afirmação pode nos surpreender. Ela reconhece os fundamentalistas religiosos como contrapúblicos "em um sentido mais forte" do que o público subalterno feminista. Warner não a desenvolve no livro, mas afirma em entrevista recente que sua pesquisa atual é sobre "como os primeiros evangélicos podem ser entendidos como um tipo de contrapúblico" e, mais adiante, que "a alt-right pode ser vista como uma versão disso [do contrapúblico]" [WARNER, 2018]. Em todo caso, este é o sentido do termo que ele termina defendendo no livro: os contrapúblicos têm alguma consciência de seu status subordinado; o horizonte cultural contra o qual eles se opõem não é só o de um público geral ou mais amplo, mas o de um público dominante; sua oposição não se limita a um conflito de ideias, mas se estende aos gêneros discursivos, aos modos de endereçamento, à hierarquia dos meios; o discurso que o constitui não é simplesmente alternativo ao público dominante, mas considerado muitas vezes como hostil ou indecoroso; sua relação conflitiva com o público dominante traz para um primeiro plano o caráter poético-expressivo de seu discurso [WARNER, 2005, p. 119-20]. 
A partir desse ponto, os exemplos de Warner são os públicos gay ou queer. O tema será retomado no capítulo Sex in Public, em uma seção intitulada Queer Counterpublics, cujo projeto de mundo inclui "modos de sentir que podem ser aprendidos mais do que experimentados como um direito inato" [WARNER, 2005, p. 198]. Assim como os públicos, os contrapúblicos se constituem por meio do endereçamento a estranhos indeterminados, mas diferentemente do discurso público, os contrapúblicos se endereçam a estranhos como não sendo quaisquer pessoas, eis que seus públicos são, antes de mais nada, marcados socialmente por sua participação num tipo de discurso do qual muitas pessoas não querem participar. Um discurso que se endereça a "qualquer um" como gay ou queer pode circular livremente, até o ponto em que se depara com algum incômodo, resistência ou reação, como veremos mais adiante no caso Queermuseu. Nesse processo, a luta individual contra o estigma social é transposta para um conflito entre modalidades daquilo que é público [publicness]. Em resumo, "os contrapúblicos são 'contra' na medida em que buscam providenciar diferentes maneiras de imaginar a sociabilidade entre estranhos e sua reflexividade" [WARNER, 2005, p. 121-2].

Como já indicamos, "o status subordinado de um contrapúblico não reflete simplesmente identida- des formadas noutro lugar; a participação [...] é uma das maneiras pelas quais as identidades de seus membros são formadas e transformadas" [WARNER, 2005, p. 121]. Desse modo, mesmo quando desafiam a hierarquia social entre a faculdade crítico-racional e a poético-expressiva, os contrapúblicos projetam o espaço da circulação discursiva entre estranhos como uma entidade social na qual suas próprias subjetividades são modeladas. Portanto, para que os fundamentalistas sejam contrapúblicos no sentido atribuído por Warner, precisariam de algum modo performar essa disponibilidade para modelar e ser modelado, em vez de simplesmente projetar a sociedade como extensão de seus valores identitários, familiares ou comunitários. Do mesmo modo, essa disponibilidade não é algo que pertença essencialmente aos públicos gay e queer, que eventualmente se organizam para defender identidades previamente concebidas, assim como fazem os públicos subalternos de Fraser.

No caso do She-Romps, essa disponibilidade aparece na iniciativa de uma de suas integrantes - que assina "Kitty Termagant" - de escrever uma carta para o spectator, relatando suas atividades em um quarto alugado, que também pode ser visto como um lugar protopúblico. Chama a atenção sua dificuldade para traduzir o que experimentam: "Não sou capaz de expressar o prazer de que 
gozamos, das dez horas da noite às quatro da manhã [...]" [TERMAGANT apud WARNER, 2005, p. 109]. Em seguida, ela lista os "trapos e farrapos" que costumam restar no chão após seus jogos libidinosos: "leques quebrados, anáguas rasgadas, restos de toucados, babados, rendas, ligas e aventais de trabalho", despojos que elas chamam de "homens mortos" [TERMAGANT apud WARNER, 2005, p. 109-10]. Há nisso um esforço de transposição. A demanda do She-Romps não é publicizar «atos privados de leitura», como faz o público do spectator. Elas almejam "abrir a intenção transformadora de suas reuniões ao distanciamento crítico do discurso público" [WARNER, 2005, p. 112]. A opacidade entre os protocolos discursivos de cada público é tamanha que Termagant decide abrir uma exceção às regras do She-Romps, convidando o "Sr." Spectator para testemunhar "pessoalmente" suas cenas noturnas, para que tenha "uma verdadeira noção do nosso esporte" - convite que é peremptoriamente recusado.

Os contrapúblicos se caracterizam, entre outras coisas, por essa disposição para se transformar entre estranhos. Enquanto os públicos dominantes tomam suas pragmáticas discursivas e mundos vitais como pressuposto, os contrapúblicos são espaços de circulação nos quais se pressupõe uma transformação do próprio espaço da vida pública. Nesse sentido, Warner admite que os públicos gay e lésbico, ao se transformarem em movimentos sociais atuantes frente ao Estado, adaptando-se para isso à pragmática do discurso crítico-racional, parecem ter ignorado ou mesmo recusado o caráter contrapúblico que os marcou historicamente. Mais do que isso, ignoraram uma condição fundamental do público discursivo, que é ser organizado independentemente de instituições formais de cidadania preexistentes [WARNER, 2005, p. 68]. Os contrapúblicos lutam para que a sociabilidade corporificada, o afeto e o jogo, enquanto atividades que não correspondem à transposição de atos privados de leitura, tenham um papel mais decisivo na constituição das relações político-sociais - o que requer tanto uma contraideologia da linguagem, quanto outro imaginário social [WARNER, 2005, p. 122-4].

Antes de retomarmos o problema dos "contrapúblicos fundamentalistas", que será objeto da quarta seção, parece-nos oportuno revisar de que modo os contrapúblicos têm sido associados aos públicos progressistas. Para isso, analisamos na próxima seção os usos do termo no/pelo campo da arte, onde suas ocorrências, apesar de situadas cultural e institucionalmente, podem refletir dinâmicas sociodiscursivas mais abrangentes. Precisamos ainda considerar que, embora os públicos [e contra- 
públicos] discursivos não possam ser confundidos com formações concretas [isto é, com pessoas que compartilham um mesmo espaço físico], tanto os frequentadores quanto os detratores da arte em museus e exposições participam de um público discursivo. Voltaremos a isso na terceira seção, onde abordamos o caso Queermuseu, no qual aquelas dimensões [discursiva e concreta] se encontram sobrepostas.

\section{USOS DO CONTRAPÚBLICO NO/PELO CAMPO DA ARTE}

A noção de contrapúblico tem figurado no debate da arte contemporânea das duas últimas décadas, sobretudo a partir de sua retomada por Michael Warner. Alguns de seus primeiros disseminadores nesse campo foram o curador, crítico de arte e professor dinamarquês Simon Sheikh [2008, 2009, 2015] e o crítico de arte e ativista cultural catalão Jorge Ribalta [2004]. Sheikh se envolveu longitudinalmente com o tema e seu trabalho teve alguma repercussão no Brasil. Ribalta foi chefe do Departamento de Atividades Culturais do Museu de Arte Contemporânea de Barcelona [MACBA], entre 1999 e 2009, quando integrou o comitê editorial da coleção que traduziu o capítulo Publics and Counterpublics para o espanhol. ${ }^{7}$ Mais recentemente, encontramos apropriações do termo pelo filósofo e professor brasileiro Rodrigo Nunes [2015], entre outros. Além das referências ao trabalho de Warner, os textos da área de artes também se referem a Nancy Fraser [1990] e, com menor frequência, ao trabalho seminal de Oskar Negt e Alexander Kluge [1993 [1972]]. Embora Warner faça uma referência muito pontual a estes dois autores, devemos creditar a eles o pioneirismo do conceito.

Avaliamos que, do ponto de vista da recepção dos discursos artísticos [representativos das práticas artísticas, curatoriais e institucionais] pelos contrapúblicos, a utilização do termo tem se dado de maneira parcial, senão problemática. Como procuramos demonstrar, alguns daqueles autores pressupõem que seria possível se associar, interagir e colaborar com os contrapúblicos. Se, por um lado, isso corresponde a uma abertura politicamente bem-intencionada, por outro, negligencia a contrapublicidade naquilo que ela tem de auto-organizado e incongruente com as agendas artístico-institucionais. Nos exemplos que vamos comentar [Ribalta, Sheikh e Nunes], o modo imprevisível e desafiador com que tais agendas são confrontadas pelos contrapúblicos resta surpreendentemente ausente ou é simplesmente aludido, como se fosse algo secundário.

Ribalta recorre ao conceito no ensaio Contrapúblicos. Mediación y construcción de públicos [2004], 
em que comenta diferentes projetos desenvolvidos pelo MACBA naquele momento, junto a comunidades locais. Sheikh, por sua vez, utiliza o conceito em uma quantidade de textos sobre curadoria na contemporaneidade. No lugar da esfera pública? Ou o mundo em fragmentos [2008] questiona a esfera pública de matriz liberal-burguesa, reunindo projetos artísticos e curatoriais que a concebem em termos fragmentários e contrapúblicos. Parte dessas ponderações também integra o texto Sobre a produção de públicos ou arte e política em um mundo fragmentado [2009], que problematiza os públicos das exposições de arte. Já no texto A Long Walk to the Land of the People: Contemporary Art in the Spectre of Spectatorship [2015], que mais abertamente se dedica à recepção artística pelos públicos, Sheikh curiosamente não utiliza o conceito - embora se refira ao Publics and Counterpublics de Warner. Nunes emprega essa categoria no texto Por uma política de contracafetinagem [2015], no qual analisa formas de colaboração, negociação e captura entre, de um lado, públicos institucionalmente legitimados e, de outro, os contrapúblicos.

A despeito de como cada autor se refere ao conceito, chama a atenção que todos atribuam aos contrapúblicos um caráter progressista. Além disso, tendem a concebê-los como comunidades subalternizadas com as quais artistas, curadores e educadores colaboram em projetos politicamente engajados. Desse modo, como já sugerimos, pressupõem que os contrapúblicos possam ser conclamados ou mesmo fortalecidos por agentes institucionais, a partir da sua posição no sistema da arte, reverberando ou mesmo suprindo as reivindicações de segmentos minorizados. Pressupõem ainda que os contrapúblicos, ao se envolver com a esfera pública da arte, pudessem desafiar ou mesmo transformar os regimes de visibilidade vigentes nesse contexto. É nesse sentido que Sheikh salienta o caráter oposicional dessas formações, assim como sua disposição para modificar os lugares em que incidem:

Contrapúblicos podem ser entendidos como formações particulares paralelas de um caráter menor ou até mesmo subordinado, onde outros discursos e práticas, até mesmo opostos, podem ser formulados e circular. Onde a clássica noção burguesa de esfera pública exigia universalidade e racionalidade, contrapúblicos frequentemente exigem o oposto e, em termos concretos, frequentemente implicam uma subversão dos espaços existentes em outras identidades e práticas. [SHEIKH, 2008, p. 130, grifos nossos]

A subalternidade associada à possibilidade de subversão e uso heterotópico dos espaços públicos e plataformas discursivas - sendo o museu de arte 
um lugar emblemático dessa conjugação - também é valorizada por Ribalta. Destacando trechos de Rethinking the Public Sphere, de Fraser, o autor parece prescindir dos "contrapúblicos performativos" de Warner em benefício do conceito mais estável "contrapúblicos subalternos", cunhado pela filósofa para se referir a espaços de "retiro e reagrupamento" e, ao mesmo tempo, "preparação para atividades de agitação", no caso, destinadas a públicos não exclusivamente feministas [FRASER apudRIBALTA, 2004, p. 3-4].

Apesar da tendência para substantivar o contrapúblico e do caráter "reformista" que o termo adquire na argumentação de Fraser [cf. WARNER, 2005, p. 119], sua vocação supostamente emancipatória e seu endereçamento aos públicos em sentido mais abrangente são dimensões presentes também no ensaio de Nunes. O filósofo destaca o caráter múltiplo dos contrapúblicos, sugerindo que suas colaborações com os agentes da arte correspondem a iniciativas marcadamente políticas:

Optar por falar em contrapúblicos plurais em detrimento do público em geral [...] não é uma simples opção por privilegiar o particular diante do universal, mas deriva de uma tomada de posição em relação ao lugar que a arte deve ocupar ao intervir em um processo social e político. [...] Ao invés de falar para o público a respeito do contrapúblico, o papel politicamente mais relevante que a arte pode assumir envolve um compromisso com ampliar a capacidade que o contrapúblico pode ter de falar por si mesmo e de agir sobre suas condições de existência e de fala, transformando-as. [NUNES, 2015, p. 1-2, grifos nossos]
Sem entrar no mérito dos critérios e estratégias adotados pelas iniciativas de ampliação das possibilidades de transformação das cenas discursivas dominantes pelos contrapúblicos, salientamos que, nas análises em questão, eles são considerados como necessariamente progressistas e potencialmente emancipatórios, dada a posição marginal que lhes é socialmente imputada e o desejo de transformação que supostamente trazem consigo. Nos textos em questão, os contrapúblicos aparecem objetivamente caracterizados como habitantes de favela, minorias sexuais e de gênero, militantes anticapitalistas, imigrantes, ativistas sociais, menores em situação de rua, associações de vizinhos etc. Daí sua importância, conforme a ótica dos autores arrolados, para os processos de abertura e pluralização almejados pelos agentes e instituições do sistema da arte.

Observamos, porém, uma dissonância entre o entendimento que os três autores têm do conceito e a compreensão do próprio Warner. Nota-se nos autores uma tendência para associar os contrapúblicos à ideia de comunidades, ou seja, a corpos coletivos identificáveis ou passíveis de serem produzidos enquanto tal. Como 
já aventamos, os contrapúblicos podem até performar esse papel, mas não em função de pertencerem a uma comunidade e sim, em virtude do modo como se relacionam aos discursos. Dessa forma, sua contrapublicidade deve ser vista como relacional e contingente, em vez de algo dado de antemão, como sugere a proposta de "colaboração com contrapúblicos". Conforme a ressalva de Warner: ou com ONGs que trabalham com crianças e adolescentes de rua. [...] Toda essa atividade não se limita ao bairro, uma vez que é parte de um contexto mais amplo de pensar e praticar modos pelos quais o museu possa contribuir para a reconstrução de uma esfera pública radicalmente democrática e, portanto, possa exercer um papel central na vida da cidade. [RIBALTA, 2004, p. 2]

Essa forma de uso da instituição artística, voltada explicitamente para o fomento de uma esfera
[...] [a cultura queer na qual se baseia o conceito de contrapúblico] difere da comunidade ou do grupo, já que necessariamente inclui mais pessoas do que aquelas que podem ser identificadas, mais espaços do que aqueles que podem ser mapeados para além de uns poucos pontos de referência, modos de sentir que podem ser aprendidos mais do que experimentados como um direito inato. [WARNER, 2005, p. 198, grifo nosso]

\section{Além da interpretação comunitarista que perpassa} os ensaios em questão, um segundo aspecto coincidente em suas análises pode ser problematizado: a ideia de que os contrapúblicos são chamados a se envolver com a arte e suas instituições mediante as iniciativas dos agentes que operam nessas instituições - por mais que elas sejam conscientes dos problemas de representação aí envolvidos. É o que se pode notar quando Ribalta detalha parte da ação do Departamento de Atividades Culturais do MACBA:

[...] Desenvolvemos projetos com comunidades específicas no bairro. Por exemplo, com grupos que trabalham com prostitutas de rua para alcançar reconhecimento legal [...], pública plural e participativa a partir da "colaboração com contrapúblicos", também é patente nas ideias de Sheikh sobre as práticas curatoriais politicamente motivadas e sua busca por reimaginar as instâncias de interação social e discursiva. Para ele, a produção de exposições comprometidas com a transformação progressista da esfera pública pressupõe a adoção de um horizonte contrapúblico:

Enquanto a noção burguesa de esfera pública lutou por racionalidade e universalidade, os contrapúblicos geralmente reivindicam o oposto e, em termos concretos, isso quase sempre vincula a mudança de espaços existentes [a] outras identidades e práticas, [assim como a] um estranhamento do espaço. Essa tem sido a forma pela qual as exposições feministas contemporâneas usam a instituição de arte como espaço para uma noção diferente de espetacularização e articulação coletiva [...], o que Marion von Osten descreve como a "produção de exposições enquanto estratégia do contrapúblico". [SHEIKH, 2009, p. 84] 
Fica evidente, tanto na descrição de Ribalta quanto na visão de Sheikh [e de von Osten, por extensão], uma aposta no aproveitamento das potencialidades políticas ensejadas pela instituição artística. Tal oportunidade, assim como as experiências que ela encoraja, são situadas por Nunes [2015, p. 1] como uma "tendência observada em práticas artísticas, curatoriais e institucionais na última década em direção a um envolvimento com questões políticas", desdobrando-se em um "ativismo artístico contemporâneo" que se distingue por lidar com "públicos diretamente mobilizados pelas questões políticas e sociais com que dialogam". O caso escolhido pelo autor para discutir os critérios de avaliação dessa "arte política" é o "envolvimento de dois anos do Grupo Comboio com a comunidade [da Favela] do Moinho" [NUNES, 2015, p. 8]. O projeto resultante desse processo foi comissionado pela $31^{\text {a }}$ Bienal de São Paulo e decidiu pela reforma do campo de futebol localizado no meio da favela paulistana - que já funcionava como o principal espaço de convivência entre os moradores.

A par dos efeitos que são perseguidos na relação com públicos e comunidades específicos, é preciso considerar as aproximações e gestos adotados pelos contrapúblicos independentemente de serem arregimentados pelas instâncias e inicia- tivas artístico-institucionais, ou que até mesmo contrariam um progressismo pretensamente compartilhado. Referimo-nos à possibilidade de que os contrapúblicos performem atitudes, discursos e expressões decididamente estranhos àqueles valorizados pelos artistas, curadores, educadores etc. O problema, contudo, não reside apenas no fato de que a lista de contrapúblicos apresentada pelos autores ignore os "contrapúblicos fundamentalistas", mas principalmente na ausência do caráter auto-organizado, imprevisível e confrontador dos contrapúblicos, nas cenas públicas de enunciação e endereçamento às quais eles se referem.

Por exemplo, como explicar que Sheikh, em seu ensaio especificamente dedicado ao "espectro da recepção" em arte, abra mão da categoria de contrapúblico? Curiosamente, estão presentes nesse texto, ainda que de maneira secundária, personagens notadamente alheios ao progressismo adotado em seus escritos anteriores. Nestes personagens, ironicamente, é possível flagrar a emergência de contrapúblicos que, em lugar de colaborar com os agentes artísticos, confrontam suas proposições: 
Para os neoconservadores, por exemplo, a emancipação está associada com a pavorosa permissividade dos anos 1960, tendo claramente ido longe demais ao deixar outras identidades saírem do armário, por assim dizer. Essa forte reação também afetou a arte contemporânea, desde os ataques do senador norte-americano Jesse Helms ao trabalho de Robert Mapplethorpe e o subsequente desmonte do National Endowment for the Arts através dos escritos de figuras como o crítico Hilton Kramer. [...] Ou ainda, [desde a] designação da arte contemporânea como um "hobby esquerdista" pelos partidos políticos de direita na Holanda, outrora orgulhosa e presuncosamente liberal. [SHEIKH, 2015, p. 256-7, grifos nossos]

Notamos, além disso, que a sua contrapublicidade se manifesta não exatamente em função do perfil conservador a prioridos personagens evocados, mas sim de seus discursos antagônicos ao consenso progressista em torno da arte. Certamente, não será possível conceber essa contrapublicidade se mantivermos intocada a ideia de que os públicos representam um desdobramento direto da imaginação artística, como parece acreditar Sheikh [2015, p. 263], juntamente com boa parte da crítica de arte associada à ideia de um público "participador": "Os públicos não devem ser entendidos apenas como aqueles que frequentam exposições e programas públicos: eles também existem como um corpo imaginário que pode a qualquer momento ser ativado".

Entendemos que os contrapúblicos não condizem exatamente com as formações imaginadas e empreitadas pelas práticas artístico-institucionais, assim como não condizem com as comunidades que se organizam para produzire difundir discursos alternativos que concernem às suas agendas políticas prévias. Eles correspondem, isto sim, às formações que, em atenção a enunciados artísticos percebidos como ameaçadores, por exemplo, mobilizam-se como que a posteriori, respondendo com discursos e expressões muitas vezes alheios aos desígnios da arte e seus agentes. Certamente, ao performar uma contraimagem do público, eles também lançam mão de plataformas discursivas, a fim de fazer circular entre desconhecidos os seus enunciados antagonistas [WARNER, 2005, p. 112]. É o que, aliás, faz deles um público.

\section{OS DETRATORES DA ARTE}

Neste ponto da discussão, parece-nos importante calibrar o estatuto "discursivo" do público de arte, que se caracteriza desse modo não tanto em função de sua presença física no ambiente expositivo, mas, principalmente, em virtude de sua atenção ao que ali é exibido. O público se faz "discursivo" por meio dos objetos semânticos que assim o definem. 
A exemplo dos leitores de jornal, os visitantes de exposição se autoproduzem performativamente como um público, no momento em que se relacionam com os discursos artísticos colocados em cena.

Ao mesmo tempo, são de algum modo projetados pelas mostras, curadorias e obras, às quais se dedicam com maior ou menor grau de diligência, constituindo-se voluntária e temporariamente como seu público. Essa dinâmica define a circularidade própria do discurso público. A relação que aí se estabelece com os objetos artísticos e partidos curatoriais envolve ainda uma contraparte responsiva. Aqui entra em cena a reflexividade do discurso público, fomentando produções distribuídas e inter-relacionadas. Na condição de discursividades públicas, as obras e curadorias artísticas, em última análise, não se dirigem a alguém em particular, mas a um público despersonalizado, que refere seus atos de recepção a uma miríade de outras respostas.

Esse processo de referenciação tece a malha citacional responsável por conferir publicidade [publicness] a uma exposição de arte. Mas, como Warner [2005, p. 95] sugere, as "controvérsias" também fazem parte dessas respostas. Nelas há posições de discordância ou mesmo de declarado antagonismo. Elas sinalizam a mesma reflexividade inerente à circulação dos discursos. Para discutir a incidência da circularidade e da reflexividade nas atividades exercidas pelos públicos de exposições de arte - esfera da qual Warner não se ocupou -, consideramos os episódios protagonizados por públicos que, durante o segundo semestre de 2017 , insurgiram-se contra eventos artísticos em diferentes cidades e instituições brasileiras, tendo como alvos privilegiados algumas exposições de arte contemporânea. Para avaliar em que medida a noção de "contrapúblicos" condiz com os detratores da arte, tomamos particularmente como referência a exposição Queermuseu: Cartografias da Diferença na Arte Brasileira[2017].

No catálogo da mostra, editado por ocasião de sua remontagem na Escola de Artes Visuais do Parque Lage no Rio de Janeiro, Gaudêncio Fidelis, seu curador, relata o que teria resultado no fechamento da exposição em Porto Alegre. Como amplamente noticiado, a mostra foi encerrada pelo Santander Cultural em 10 de setembro de 2017 - um mês antes da data inicialmente prevista. ${ }^{8}$ Segundo Fidelis, a medida foi tomada pela instituição com "apenas dois dias e algumas horas de manifestações do Movimento Brasil Livre [MBL]". Para o curador, militantes do grupo teriam entrado na exposição "produzindo vídeos e fotografias" que serviram para a construção de "uma narrativa difamatória de forte caráter moralista sobre a exposição". Isso a despeito de se basearem, como Fidelis enfatiza, 
em apenas cinco obras da exposição [ESCOLA DE ARTES VISUAIS DO PARQUE LAGE, 2018, p. 19]. ${ }^{9}$

Baseando-se na acusação de que a mostra fazia apologia à zoofilia e à pedofilia, além de blasfemar símbolos cristãos, essa narrativa se difundiu pelas redes sociais digitais. Isso demonstra a circularidade indeterminada dos conteúdos da Queermuseue a reflexividade que ela propiciou enquanto discurso público. Contudo, a versão de Fidelis omite que não fora o MBL quem deflagrou os ataques, e que os mesmos tiveram início em 06 de setembro de 2017.

Considerar o encadeamento citacional em questão também é importante para se perceber aquela circularidade e reflexividade. Uma matéria da revista Época documenta que, na manhã do dia 06, Cesar Augusto Cavazzola Jr., advogado e professor de Direito de Passo Fundo [RS], postou um texto de sua autoria num site de perfil conservador [TAVARES; AMORIM, 2017]. Suas linhas expõem a indignação diante da mostra por ele visitada dias antes, expressando repúdio ao que chamou de "ataques à moral e aos bons costumes". Sua publicação é considerada a primeira rejeição rastreada à exposição. Dentre as iniciativas subsequentes, destaca-se a de Felipe Diehl, ex-militar e segurança patrimonial de Porto Alegre, que visitou a mostra no dia da postagem de Cavazzola Jr. Em vídeo gravado no espaço expositivo, ele classifica as obras de "putaria" e "sacana- gem", além de abordar educadores da exposição, perguntando se eles eram "tarados" ou "pedófilos". Amigo de Diehl, o blogueiro Rafinha BK também filmou obras in loco, fazendo comentários que as abominavam. Os vídeos viralizaram a partir de suas postagens no dia 08, sendo sucedidos por um sem número de manifestações de repúdio à mostra, via redes sociais e e-mails enviados aos funcionários do Santander, assim como pela depredação de agências do banco em diferentes cidades do país.

É somente no dia 10 que o MBL passa a influir - ao menos publicamente - no curso dos acontecimentos, data em que o Santander encerrou a mostra e publicou uma nota acerca de sua decisão. A primeira manifestação do grupo sobre o caso se deu por meio de postagem no Facebook, embora Renan Santos, um dos fundadores do MBL, afirme que a mobilização via WhatsApp havia começado antes, mesmo que nenhum de seus membros tenha visitado pessoalmente a exposição. Isso sugere que a campanha difamatória encampada pelo grupo teve como principais referências o texto de Cavazzola Jr. e os vídeos de BK e Diehl. O último inclusive chegou a se mostrar ressentindo com o fato de os créditos pelo fechamento da exposição terem ficado com o MBL - identificado por ele como um grupo "socialista fabiano" [sic], que teria uma posição de esquerda, comprometida com o Estado provedor. 
Diante de episódios como esse, com as consequências que produziu e segue produzindo no ambiente sociopolítico e cultural brasileiro, ${ }^{10}$ é oportuno retornarmos à concepção de público de Sheikh "como um corpo imaginário que pode a qualquer momento ser ativado". Como observamos, as prerrogativas dessa "imaginação ativadora" tendem a ser reservadas aos agentes da arte, em correspondência a uma renitente positivação dos contrapúblicos. Algo dessa lógica se deixa apreender nas palavras do então Diretor-Presidente da Escola de Artes Visuais do Parque Lage, Fabio Szwarcwald, que no texto institucional para o catálogo da exposição alinha a escola carioca às "instituições que desejam se posicionar à frente do seu tempo [sic] em plena sintonia com o sofisticado público do século XXI" [ESCOLA DE ARTES VISUAIS DO PARQUE LAGE, 2018, p. 10]. " Considerando o teor supostamente vanguardista e elitista do endereçamento, o que fazer com os públicos menos "sofisticados" do agora? Como reconhecer e lidar com os desafios que eles nos impõem?

Enfrentá-los solicita levar a sério suas ações, dentre as quais estão os ataques à Queermuseu. Como o próprio Fidelis reconheceu, tais ações revelaram "posições até então não imaginadas como forma de manifestação e julgamento em relação a uma exposição de arte" [grifo nosso]. O curador as des- creve como um "processo difamatório que engoliu e submergiu a exposição em um terremoto de infâmia" [ESCOLA DE ARTES VISUAIS DO PARQUE LAGE, 2018, p. 47]. São inúmeros os argumentos que ele apresenta, buscando deslegitimar a onda detratora: [i] a incoerência com a narrativa original da exposição e sua estrutura conceitual; [ii] o equívoco e falsidade das informações circuladas, estranhas à natureza da exposição; [iii] o engajamento majoritariamente descolado da frequentação presencial à mostra; [iv] a eleição de um pequeno número de obras ou detalhes para generalizar o conteúdo da exposição; [v] a confusão entre representação e realidade, entre crítica e apologia; [vi] a deturpação, remontagem e ficcionalização de aspectos das obras; [vii] o uso de robôs, a manipulação dos algoritmos e o impulsionamento de postagens nas redes; [viii] a premeditação fundamentalista em função de uma "guerra santa"; [ix] a mobilização conservadora da noção de "ideologia de gênero"; [x] os interesses econômicos e clientelistas da instituição financeira promotora da mostra; [xi] a busca de base eleitoral por agentes políticos neoliberais e reacionários; [xii] a agressividade com que os indignados se manifestaram, incluindo abordagens violentas de visitantes, trabalhadores da exposição e do próprio curador [ESCOLA DE ARTES VISUAIS DO PARQUE LAGE, 2018, p. 11-51]. 
Apesar do compromisso desses argumentos com a defesa da exposição, eles não apenas negligenciam a circularidade e a reflexividade do discurso público, como também acabam sobrepujados pelas formas de apreensão e rechaço praticadas pelos detratores da Queermuseu. Se consideramos a controvérsia pelo viés performativo e da circularidade dos públicos, os argumentos do curador parecem desinformados do funcionamento da arena pública discursiva, marcada por recepções e respostas conflitivas ou mesmo antagônicas. Nesse campo de enunciação distribuída entre estranhos, as demandas por fidelidade ao discurso "original" e à "natureza" da exposição não se sustentam. Tampouco se sustenta a afirmação de que grande parte dos detratores sequer visitou a exposição, uma vez que um público é formado, não por sua presença física em determinado espaço, mas por sua atenção ao discurso veiculado. Também não faz sentido exigir que, para poder falar sobre a exposição, o público esteja apropriado de todo o seu conteúdo, inclusive porque a eleição de obras específicas para representar uma exposição é prática corrente tanto das suas estratégias de divulgação, quanto da crítica especializada.

A confusão entre metáfora e literalidade, por sua vez, não pode ser acusada de ilegítima, se considerarmos que, na "condição pós-autônoma da arte"
[CANCLINI, 2016, p. 23], os critérios do mundo comum concorrem para desarticular a especificidade artística - incluídas aí sua ficcionalidade e criticidade. Deturpação e remontagem do discurso público são expedientes da sua reflexividade, responsável pela dinâmica citacional da qual depende o discurso para se fazer público. Por sua vez, apontar o uso de artifícios técnicos para anabolizar os efeitos dos ataques subestima a onda detratora, como se ela fosse fake. Sobre o caráter fundamentalista e conservador dos ataques, isso reflete as "guerras culturais" [HUNTER, 1991; HARTMAN, 2016; ORTELLADO, 2018] em que estamos vivendo - o que justamente precisaria ser considerado. Isso para não dizer dos interesses autopromocionais da instituição realizadora da exposição, de cuja engrenagem Fidelis aceitou participar, tendo em vista que o marketing cultural tem por motor a captura e instrumentalização de imaginários artísticos. Dessa vez, isso não se deu apenas a título de «valor agregado» à marca do banco ou de "sala de visita" para a sua clientela, mas como curral eleitoral do MBL, em seu gesto de "captura da captura".

A violência das manifestações e as respectivas manobras discursivas deflagradas por Cavazzola Jr., Diehl e BK - catalisadas e capitalizadas pelo MBL -, podem ser consideradas pela ótica poético-expressiva como indecorosidade, isto é, como a forma 
destituída de credibilidade e confiança com que os contrapúblicos irrompem na esfera pública. Neste ponto, podemos nos perguntar se os detratores da arte podem ser reconhecidos como contrapúblicos. Noutros termos, em que medida essa categoria analítica se presta a traduzir os atos discursivos mobilizados nos ataques a exposições de arte ou, inversamente, de que forma os autores desses ataques performam a contrapublicidade nos termos delineados por Warner com base nas discursividades queer? O caso Queermuseu não poderia ser mais oportuno para indagações desse tipo. A seguir, discutimos a pertinência de se atribuir uma contrapublicidade aos públicos conservadores.

\section{CONTRAPÚBLICOS CONSERVADORES}

Como dissemos, Warner [2018] afirma em entrevista recente que sua pesquisa atual é sobre "como os primeiros evangélicos podem ser entendidos enquanto um tipo de contrapúblico" e, mais adiante, que "a alt-right pode ser vista como uma versão disso [do contrapúblico]". Mais do que reconhecer a existência de contrapúblicos conservadores [ou fundamentalistas, nacionalistas, ultraliberais, rancorosos etc.], Warner introduz uma diferença "interna" entre eles. Enquanto os evangélicos do século XVIII atuavam "tentando retirar as pessoas do que eles entendiam ser a cultura dominante", a alt-right de 2016 - um ator decisivo na eleição de Donald Trump à presidência dos Estados Unidos - se empenha em "se tornar o público dominante". Essa contradição atual, segundo Warner, está em toda parte. A diferença que ele demarca é menos entre evangélicos e trolls do que entre subcategorias de contrapúblicos conservadores. Em todo caso, ambos compartilham, além da "consciência de sua própria marginalidade", uma "vontade de converter estranhos" e um "uso agressivo das mídias públicas".

Ainda nessa entrevista, Warner sugere que os contrapúblicos conservadores, assim como os contrapúblicos em geral, existem desde que há públicos. Apesar disso, como no caso dos "contrapúblicos subalternos" de Fraser, os contrapúblicos têm sido principalmente associados aos públicos progressistas. Se, por um lado, o fato de desafiarem os públicos dominantes sugere essa associação, por outro, o sentimento de marginalidade, entre outros aspectos, não é exclusividade dos públicos progressistas. Como explicar esse fenômeno? Nos últimos anos, em meio ao que diferentes autores chamaram de "fadiga da democracia" [APPADURAI, 2017], "populismo reacionário" [FRASER, 2017], "era do ressentimento" [MISHRA, 2017], "de-civilização" [NACHTWEY, 2017], "era da regressão" [GEISEL- 
BERGER, 2017] etc., pudemos observar algumas "mudanças na estrutura de oportunidades políticas" [ROCHA, 2019], que por sua vez propiciaram uma mudança na própria estrutura dos contrapúblicos. Segundo Malin Holm [2019], "o surgimento recente na internet de contradiscursos racistas, antifeministas e negacionistas [...] levanta novas questões sobre como podemos entender e analisar o poder e o privilégio nas esferas públicas". A seguir, buscamos indicar algumas dessas questões.

Em sua pesquisa sobre os "contrapúblicos ultraliberais", Camila Rocha [2019, p. 132] avalia que "[...] a mudança mais significativa na redefinição dessa categoria foi o abandono da ideia de que o atributo central dos contrapúblicos seria a condição subalterna de seus membros". A cientista política credita a Warner uma contribuição destacada nesse processo. Sua avaliação não deixa de estar correta, particularmente a respeito dos limites de Fraser em relação a Warner, mas ela também é parcial. Voltaremos a isso mais adiante, mas, basicamente, assim como Sheikh, Ribalta e Nunes, Rocha também desreconhece a dimensão performativa dos contrapúblicos. Em todo caso, a mudança em questão implica não só uma ampliação do escopo dessa categoria, de modo a abarcar diferentes tipos de contrapúblicos [progressistas e conservadores, subalternos e não subalternos], mas uma apropriação por parte da direita que ascendeu nos últimos anos de técnicas, estilos ou estratégias até então associadas à esquerda, além de uma fragmentação do que até então era considerado público dominante. Segundo Angela Nagle [2017, p. 29], "a facilidade com que esse ambiente alt-righte alt-light mais amplo pode hoje usar estilos transgressores mostra o quão superficial e historicamente acidental é a associação desses estilos com a esquerda socialista".

Nagle não emprega o termo "contrapúblicos", mas entende que a habilidade da direita digital para "assumir a estética da contracultura, da transgressão e da inconformidade nos diz muita coisa sobre [...] o establishment liberal contra o qual ela se define" [NAGLE, 2017, p. 28]. Devemos sublinhar que, nos Estados Unidos, o termo "liberal" - conforme a divisão entre liberais e conservadores enquanto categorias para se pensar a política nesse país corresponde grosso modo aos setores progressistas ou democratas da sociedade [LAKOFF, 2002]. Também podemos considerar que a alt-right norteamericana chegou a se autodenominar "libertarian" [NAGLE, 2017, p. 13-4], enquanto no Brasil, onde o liberalismo e o conservadorismo se associam, ${ }^{12}$ o termo "libertário" não pegou, segundo Rocha [2019, p. 133], por remeter ao anarquismo. Em todo caso, o comentário de Nagle sugere não 
só uma caracterização da alt-right como contrapúblico, mas também da esquerda como público dominante. De fato, a fragmentação da esfera pública, como veremos a seguir, fez com que tanto a alt-right quanto os ultraliberais se referissem simultaneamente a pelos menos dois públicos dominantes: um à esquerda e outro à direita.

Rocha entende que o conceito de contrapúblicos pode ser frutífero "para compreender a expressão de atores que não são oprimidos socialmente, mas que se percebem marginalizados na esfera pública". No caso dos ultraliberais, trata-se de contrapúblicos das classes média e alta, que se organizaram a partir de comunidades no Orkut, em um momento no qual o acesso à internet no Brasil era restrito a uma elite econômica e cultural. Apesar de sua condição privilegiada, os ultraliberais compartilham um "sentimento de marginalidade", uma "sensação de silenciamento", especialmente em relação aos públicos acadêmicos, que percebem como sendo "dominados culturalmente pela esquerda" e fechados para "um debate franco acerca de questões políticas e econômicas". A ideia de que são "vítimas do esquerdismo" os diferencia tanto da esquerda que eles chamam de "comunista" ou "bolivariana", quanto de setores à direita que consideram limitados. A defesa peessedebista de um neoliberalismo de terceira via, por exemplo, é para eles sinônimo de "esquerdis- mo" [ROCHA, 2019, p. 125-6, 135, 153-4]. Do mesmo modo, os primeiros detratores da Queermuseu imputaram ao MBL um suposto "socialismo fabiano".

Outro componente da mudança a que nos referimos é a perda por parte da esquerda do monopólio sobre a mobilização social, a partir das manifestações de 2015 em favor do impeachment de Dilma Rousseff, se não desde 2013. Nesse processo, os defensores radicais do livre mercado são apenas uma das "ideias-força" que organizam a mobilização, juntamente com o antipetismo e o conservadorismo moral [MESSENBERG, 2019]. Em um artigo a respeito da influência da alt-right sobre o bolsonarismo, Rodrigo Nunes [2020] entende que a nova extrema direita, ao assumir a posição do troll, logrou "posicionar-se como a voz dos desejos antissistêmicos ao mesmo tempo em que associava a esquerda [...] ao establishment, a uma cultura "uncool' e ultrapassada, ao controle de pensamento". Segundo o filósofo, o trol/ seria justamente "alguém que busca instigar reações fortes e parece se alimentar da própria capacidade de causar confrontos e expor os outros ao ridículo". A descrição não só o aproxima do contrapúblico, como também do artista de vanguarda, por contrafação da ideia de épater la bourgeoisie.

No campo cultural, a ideia de uma "hegemonia esquerdista" encontra respaldo não só em Olavo 
de Carvalho, como também - embora neste caso se refira a um momento particular da história do país - em Roberto Schwarz [2008 [1970], p. 71], para quem "a presença cultural da esquerda não foi liquidada naquela data [em 1964], e mais, de lá para cá não parou de crescer". Essa hegemonia, a propósito, é um dos principais fatores para o surgimento das chamadas "guerras culturais", em resposta às conquistas por direitos civis a partir dos anos 1960 [HUNTER, 1991; HARTMAN, 2016] ou, no caso do Brasil, em resposta às conquistas da redemocratização e da Constituição de 1988 [ORTELLADO, 2014]. Como lembra Nagle [2017, p. 57], "às vezes se diz que a direita ganhou a guerra econômica e que a esquerda ganhou a guerra cultural". Da sua perspectiva, é o reconhecimento de que a identidade cultural triunfou sobre a igualdade econômica, em termos de expectativas sociais, o que leva a direita digital a adotar uma política identitária à sua maneira, que tem "mais o espírito desbocado dos comentários em threads feitos pelos trolls do que o dos estudos bíblicos, mais Clube da Luta do que valores familiares".

Para Rocha [2019, p. 132 e 165], haveria dois fatores principais condicionando a mudança em questão: uma popularização ambivalente da internet, que tanto democratiza quanto fragmenta a esfera pública, e o que Robin Celikates [2015] chama de uma "multiplicidade de esferas públicas - mais ou menos locais, mais ou menos integradas, mais ou menos oficiais e institucionalizadas, e mais ou menos digitalizadas". As mudanças a que a pesquisadora se refere envolvem uma crise das instituições democráticas e do sistema representativo em geral, que se aprofunda desde 2013. Nesse processo, o próprio papel mediador da esfera pública [ou das esferas públicas] entre a sociedade civil e as instituições políticas assume um funcionamento diverso, em que a legitimidade daquilo que diria respeito ao comum perde qualquer estabilidade. Certamente, a digitalização dessas instâncias - que deve ser entendida como um processo "complexo e multifacetado" [CELIKATES, 2015] - massifica os espaços de convocação, engajamento e contestação. Porém, na medida em que suas operações são incontornavelmente editadas pela economia da atenção, podem inclusive ser revertidas em favor de seus próprios adversários [NUNES, 2020].

Em sua leitura de Michael Warner, Camila Rocha [2019, p. 133] entende que "a despeito de serem subalternos ou não, [os membros de um contrapúblico] partilhariam identidades, interesses e discursos [...]". De fato, com base nas entrevistas que realizou, os ultraliberais se percebem como "parte de uma mesma coletividade, organizada na forma de um contrapúblico"; que entre eles foi se cristalizando 
"uma identidade coletiva"; que eles partilhavam "um sentimento de pertencimento"; que existia no movimento uma "sensação de família" [ROCHA, 2019, p. 136, 153, 155 e 166]. Nossa leitura, diferentemente, demonstrou que os contrapúblicos não podem ser definidos de forma substantiva, muito menos identitária; que o que eles "compartilham" é da ordem de uma performatividade; que a sua configuração "coletiva" remete a uma sociabilidade entre estranhos. Mas se, por um lado, a leitura de Rocha parece limitada pela categoria dos contrapúblicos não subalternos, por outro, sua descrição da formação e institucionalização dos contrapúblicos ultraliberais nos permite analisar com mais precisão o que Warner chama de contrapúblicos que se empenham para se tornar dominantes.

Há diferentes momentos nesse processo que não podem ser confundidos: entre apropriações do Orkut por jovens universitários e a ascensão de lideranças que impactaram significativamente a política nacional, a ponto de conquistarem uma centralidade para sua agenda na equipe econômica do $38^{\circ}$ Presidente da República, não podemos ignorar a preexistência de uma rede de think tanks liberais disposta a oferecer apoio organizacional e financeiro à militância em formação [ROCHA, 2019, p. 125-6 e 166]. Uma das diferenças entre aquele processo e a transformação dos públicos gay e lésbico em movimentos sociais comentada por Warner é que estes o fazem por adaptação à pragmática do discurso crítico-racional, enquanto os ultraliberais se institucionalizam radicalizando a agressividade poético-expressiva que os caracteriza enquanto contrapúblicos. Serão mais ou menos contrapúblicos por isso? Trata-se de uma agressividade indecorosa, que se julga "moralmente superior" e que, no caso do bolsonarismo, é percebida por seus apoiadores como indicativo de que o Presidente é "sincero", "autêntico" e "verdadeiro” [ROCHA et al., 2020]. Nela, entretanto, não reconhecemos a disponibilidade para modelar e ser modelado, característica dos contrapúblicos performativos e progressistas.

\section{CONSIDERAÇÕES FINAIS}

Tanto os autores que associam os contrapúblicos a ações políticas progressistas, quanto os que, ao contrário, entendem que eles não correspondem exclusivamente a identidades subalternas, desreconhecem o caráter performativo dos contrapúblicos. As razões para que isso ocorra excedem o que foi analisado neste artigo, mas supomos que a intratabilidade das formações contrapúblicas pelas estratégias de mobilização política - em função de seu caráter emergente, autoproduzido, 
extrainstitucional etc. - seja um dos motivos para se relegar o performativo. Os contrapúblicos são algo de que se possa participar, mas não algo a que se possa pertencer. Logo, não podem ser agenciados nem dominados - embora eventualmente sejam, como vimos, catalisados e capitalizados. Em última análise, reconhecer o performativo implica abrir mão dos contrapúblicos como um conceito crítico-normativo a priori, para pensá-lo e experimentá-lo como um método capaz de descrever e analisar a posteriori diferentes alianças ou assemblages de contestação pública [THIMSEN, 2017].

Se por um lado a subalternidade deixa de caracterizar os contrapúblicos suficientemente, por outro, o performativo fornece outros critérios para descrevê-los empiricamente: o poético-expressivo, a corporeidade, a indecorosidade etc. O ponto é que esses critérios se encontram distribuídos tanto à esquerda quanto à direita do espectro político. Segundo Freya Thimsen [2017], enquanto os contrapúblicos foram pensados como subalternos, sua valência crítico-normativa andou junto com sua função analítico-descritiva. Com a disjunção dessas instâncias, a função dos contrapúblicos deixa de estar necessariamente comprometida com os valores e práticas democráticos. Analisando o trumpismo, a pesquisadora entende que esse contrapúblico contestou o modelo dominante de financiamento das campanhas eleitorais. Contudo, ao posicionar Trump como a única solução para enfrentar a interferência plutocrática dos ricos e dos grandes conglomerados de mídia na política, o trumpismo não se comprometeu com a ampliação da democracia, no sentido do combate às injustiças sociais.

A esta altura, porém, a tentativa de restaurar a dimensão crítico-normativa dos contrapúblicos, no sentido de fazer com que o conceito se apoie sobre pressupostos democráticos, pode comprometer sua capacidade analítico-descritiva. Uma das características dos contrapúblicos, no entanto, resta como dificilmente associável aos públicos conservadores: a disponibilidade para modelar e ser modelado. Diferentemente da vontade de converter estranhos, trata-se de uma disponibilidade para se transformar entre estranhos; de uma abertura efetiva para as mais diversas e imprevistas diferenças. Mas isso tampouco se encontra facilmente associado aos públicos progressistas, ao menos enquanto movimento ou organização. Segundo Richard Sennett [2015, p. 19], "A sociedade moderna está gerando um novo tipo de caráter. É o tipo de pessoa empenhada em reduzir ansiedades provocadas pelas diferenças [...]. O objetivo da pessoa é evitar qualquer sobressalto, sentir-se o menos estimulada possível por diferenças profundas". 
Para o sociólogo, essa "socialidade" contrasta com a solidariedade, que pode basicamente se estabelecer de duas formas distintas: de cima para baixo, enfatizando a unidade, a coalizão, o consenso e a organização; ou de baixo para cima, enfatizando a inclusão, a cooperação, a reciprocidade e a informalidade. A segunda, certamente mais receptiva àquela disponibilidade para se transformar entre estranhos, não condiz com a política dos meios voltados para fins, podendo não levar a resultado algum. Daí certa incompatibilidade entre os contrapúblicos e sua institucionalização enquanto movimento social. Mais do que o poético-expressivo, é o próprio performativo que pareceria sacrificado nesse processo. Porém, quando mesmo a socialidade tende a ser suplantada por uma vontade de anulação das diferenças, é justamente aquela disponibilidade que, de algum modo, precisaria ser performada, suscitando redes em que a transformação possa existir, circular e ser compartilhada. Certamente, é o próprio conceito que se transforma nesse processo, para se tornar um conceito exposto às suas próprias diferenças internas.
NOTAS

1 Em 2016, por ocasião de nossa edição do sexto número do Periódico Permanente, publicação promovida pela plataforma de ação e mediação cultural Fórum Permanente, promovemos a tradução para o português da "versão abreviada" do capítulo Publics and Counterpublics do livro de Warner, versão esta produzida e veiculada pelo próprio autor. A tradução ficou a cargo da mediadora Ethienne Nachtigall, convidada por nós, editores, para esse fim. Disponível em hitps:/ / bit.ly/3u2Ahc4. Acesso em 19/5/2021.

2 Todas as citações cujas referências estão em língua estrangeira têm tradução nossa.

3 Essa é a proposta de Nancy Fraser, no artigo Rethinking the Public Sphere: A Contribution to the Critique of Actually Existing Democracy [1990].

4 Warner emprega o termo "drag queen" para se referir às frequentadoras da casa. Já o livro Casa Susanna, editado em 2005 por Michael Hurst e Robert Swope, emprega o termo "cross-dressers".

5 Distinguindo-se das noções de "público como totalidade social" [pertencente a certa nacionalidade, sociedade, estado, cidade etc.] e, também, de "públicos como formações concretas" [presentes em espetáculos teatrais, exposições de arte, sessões de cinema, procissões religiosas, protestos de rua etc.], o conceito de "públicos discursivos" deriva de experiências comunicacionais tipicamente modernas, inicialmente ligadas às culturas da imprensa e do livro. Nesse sentido, os "públicos discursivos" se autoproduzem performativamente na relação com textos e outros artefatos que circulam entre desconhecidos. Essa circularidade indefinida do discurso público é necessariamente 
acompanhada por um tipo de reflexividade, caracterizada por citações e respostas públicas a esse mesmo discurso.

6 Essa circularidade é ilustrada por Warner com o "enigma do ovo e da galinha": o discurso não existe senão mediante seu endereçamento a um público, que por sua vez só existe mediante a atenção dispensada ao discurso que the é endereçado.

7 capítulo Publics and Counterpublics do livro homônimo de Michael Warner foi traduzido e editado em forma de brochura pelo MACBA, em parceria com a Universidade Autônoma de Barcelona, no ano de 2008.

8 episódio de seu fechamento foi sucedido por uma série de outros eventos, em diferentes cidades brasileiras [Campo Grande, Jundiaí, São Paulo, Belo Horizonte, Fortaleza, Vitória, Brasília], chegando à condução coercitiva do curador da exposição em 08 de novembro do mesmo ano, mediante requerimento aprovado pela CPI dos Maus-tratos. Nesta seção, abordaremos o caso Queermuseu com um propósito particular, interessado em demonstrar sua circularidade e reflexividade, sem a pretensão de discuti-lo exaustivamente. Outros aspectos do mesmo caso foram discutidos em textos nossos anteriores [ver HONORATO, 2019; SILVA, 2018].

9 As obras são: Cena de interior // [1994], de Adriana Varejão; Travesti da lambada e deusa das águas [2013] e Adriano bafônica e Luiz França She-há [2013], de Bia Leite; Cruzando Jesus Cristo com Deusa Shiva [1996], de Fernando Baril; e Et Verbum [2011], de Antonio Obá.

10 Exemplo recente dessas consequências é a aprovação de projeto pela Câmara Legislativa do Distrito Federal, proibindo a nudez em exposições realizadas nessa unidade federativa [CRUZ, 2020].

11 A primeira tentativa de remontagem da exposição na cidade do Rio de Janeiro, prevista para o Museu de Arte do Rio
[MAR], fora vetada com traços de desdém pelo então Prefeito Marcelo Crivella. A transferência da exposição para a Escola de Artes Visuais do Parque Lage, instituição ligada ao governo do estado, contou com campanha de financiamento coletivo amplamente encampada pela sociedade civil.

12 Entrevistando Kim Kataguiri, um dos líderes do MBL, sobre a adoção das guerras culturais pelo movimento, a jornalista Anna Virginia Balloussier [2017, grifo nosso] transcreve: "Esse distanciamento [em relação à moral, aos costumes, às tradições], segundo ele [Kataguiri], 'levou a uma derrota política acachapante para a direita, porque as pessoas, antes de se preocuparem com o que é economicamente viável, se preocupam com o que é justo. A gente esqueceu de focar no discurso da justiça - que o MBL trouxe de volta para o liberalismo e o conservadorismo brasileiros'". Mais uma vez, o caso Queermuseu demonstra essa associação. 
APPADURAI, Arjun. Une fatigue de la démocratie. In GEISELBERGER, Heinrich [ed.]. L'âge de la régression. Paris: Gallimard, 2017, p. 17-37.

BALLOUSSIER, Anna Virginia. Moral e costumes entram em foco em congresso do MBL. Folha de São Paulo, 11 nov. 2017. Disponível em https://bit.ly/3oDKFoF. Acesso em 8/12/ 2020.

CANCLINI, Nestor García. A Sociedade sem Relato: antropologia e estética da iminência. São Paulo: Editora da Universidade de São Paulo, 2016.

CELIKATES, Robin. Digital publics, digital contestation: a new structural transformation of the public sphere? In CELIKATES, Robin; KREIDE, Regina; WESCHE, Tilo [org.]. Transformations of democracy. crisis, protest and legitimation. London: Rowman \& Littlefield International, 2015, p. 159-75.

CRUZ, Carolina. Câmara Legislativa aprova projeto que proíbe nudez em exposições culturais públicas no DF. G1 DF, 18 ago. 2020. Disponível em https://glo.bo/37BcHdz. Acesso em 25/11/2020.

ESCOLA DE ARTES VISUAIS DO PARQUE LAGE. Queermuseu: cartografias da diferença na arte brasileira. Organização, curadoria e textos de Gaudêncio Fidelis. Rio de Janeiro: AMEAV, 2018.

FRASER, Nancy. Rethinking the Public Sphere: A Contribution to the Critique of Actually Existing Democracy. Social Text, n. 25/26, p. 56-80, 1990. Disponível em https://bit.ly/3oLvXMv. Acesso em 8/12/2020. 
FRASER, Nancy. Néolibéralisme progressiste contre populisme réactionnaire: un choix qui n'en est pas un. In GEISELBERGER, Heinrich [ed.]. L'âge de la régression. Paris: Gallimard, 2017, p. 60-77.

GEISELBERGER, Heinrich [ed.]. L'âge de la régression. Paris: Gallimard, 2017.

HABERMAS, Jürgen. Mudança estrutural da esfera pública: investigações sobre uma categoria da sociedade burguesa. São Paulo: Editora Unesp, 2014.

HARTMAN, Andrew. A War for the Soul of America: A History of the Culture Wars. Chicago; London: The University of Chicago Press, 2016.

HOLM, Malin. The Rise of Online Counterpublics? The limits of inclusion in a digital age. Uppsala, 2019. PhD Thesis, Uppsala University: Department of Government. 246 pp.

HONORATO, Cayo. Mediação cultural em meio às controvérsias. Palíndromo, Florianópolis, v. 11, p. 99-113, 2019. Disponível em https://bit.ly/2SXitSZ. Acesso em 19/5/2021.

HUNTER, James Davison. Culture Wars: The Struggle to Define America. New York: Basic Books, 1991.

LAKOFF, George. Moral Politics: How Liberals and Conservatives Think. Chicago; London: The University of chicago Press, 2002.

MESSENBERG, Débora. A direita que saiu do armário: a cosmovisão dos formadores de opinião dos manifestantes de direita brasileiros. In ROCHA, Camila; SOLANO, Esther [org.]. As direitas nas redes e nas ruas: a crise política no Brasil. São Paulo: Expressão Popular, 2019, p. 175-213.

MISHRA, Pankaj. La politique à l'ère du ressentiment. Le sombre héritage des Lumières. In GEISELBERGER, Heinrich [ed.]. L’âge de la régression. Paris: Gallimard, 2017, p. 171-194. 
NACHTWEY, Oliver. La dé-civilisation. Sur les tendances régressives à l'ouvre dans les sociétés occidentales. In GEISELBERGER, Heinrich [ed.]. L'âge de la régression. Paris: Gallimard, 2017, p. 217-236.

NAGLE, Angela. Kill All Normies: Online Culture Wars from 4Chan and Tumblr to Trump and the Alt-Right. Winchester; Washington: Zero Books, 2017.

NEGT, Oskar; KLUGE, Alexander. Public sphere and experience: toward an analysis of the bourgeois and proletarian public sphere. Minneapolis; London: University of Minnesota Press, 1993 [1972].

NUNES, Rodrigo. Alvim errou a mão na trollagem nazi inspirada na direita dos EUA. Folha de São Paulo, 21 jan. 2020. Disponível em https://bit.ly/3IVOW4U. Acesso em 8/12/2020.

NUNES, Rodrigo. Por uma política de contracafetinagem. Mesa, Rio de Janeiro, n. 3, mai. 2015. Disponível em https://bit.ly/2VRQhPF. Acesso em 28/112020.

ORTELLADO, Pablo. Guerras culturais no Brasil. Le Monde Diplomatique, 01 dez. 2014. Disponível em https:// bit.ly/33U5STr. Acesso em 8/12/2020.

ORTELLADO, Pablo. Conservadores temem entregar a família aos quatro cavaleiros do apocalipse. Folha de São Paulo, 2/1/2018. Disponível em https://bit.ly/30xn5tr. Acesso em 28/11/2020.

REPA, Luiz Sérgio. Sobre o conceito habermasiano de esfera pública. Número, São Paulo, v. 6, 2005. Disponível em https://bit.ly/3grQXoA. Acesso em 3/12/2020.

RIBALTA, Jorge. Contrapúblicos. Mediación y construcción de públicos. Transform, EIPCP, 2004. Disponível em https://bit.ly/39VtP0e. Acesso em 28/11/2020. 
ROCHA, Camila. "Imposto é roubo!" A formação de um contrapúblico ultraliberal e os protestos pró-impeachment de Dilma Rousseff. In ROCHA, Camila; SOLANO, Esther [org.]. As direitas nas redes e nas ruas: a crise política no Brasil. São Paulo: Expressão Popular, 2019, p. 123-74.

ROCHA, Camila; RIBEIRO, Marcio Moretto; MEDEIROS, Jonas. O contrapúblico bolsonarista e o negacionismo da pandemia. Novos Estudos, 10 jul. 2020. Disponível em https://bit.ly/3oyzs8F. Acesso em 8/12/2020

SCHWARZ, Roberto. Cultura e política, 1964-1969. In SCHWARZ, Roberto. O pai de família e outros estudos. São Paulo: Companhia das Letras, 2008, p. 70-111.

SENNETT, Richard. Juntos. Rio de Janeiro: Record, 2015.

SHEIKH, Simon. A Long Walk to the Land of the People: Contemporary Art in the Spectre of Spectatorship. In HLAVAJOVA, Maruaa; HOSKOTE, Ranjit [ed.]. Future Publics [The Rest Can and Should Be Done by the People]: A Critical Reader in Contemporary Art. Utrecht: BAK basis actuele kunst, 2015, p. 232-63.

SHEIKH, Simon. No lugar da esfera pública? Ou o mundo em fragmentos. Urbânia, São Paulo, n. 3, p. 127$35,2008$.

SHEIKH, Simon. Sobre a produção de públicos ou arte e política em um mundo fragmentado. In CAMNITZER, Luis; PÉREZ-BARREIRO, Gabriel [org.]. Arte para a educação / educação para a arte. Porto Alegre: Fundação Bienal do Mercosul, 2009, p. 74-88.

SILVA, Diogo de Moraes. Públicos controversos - entrevista com Daniela Labra. Políticas Culturais em Revista, v.11, n. 1, p.168-196, 2018. Disponivel em https://bit.ly/2RuZCOR. Acesso em 19/5/2021.

TAVARES, Flávia; AMORIM, Daniele. Como movimentos ultraconservadores conseguiram encerrar a exposição Queermuseu. Época, 15 set. 2017. Disponível em https://glo.bo/3qB9X8B. Acesso em 8/12/2020. 
THIMSEN, Freya. Did the Trumpian Counterpublic Dissent Against the Dominant Model of Campaign Finance? Journal of the European Institute for Communication and Culture, v. 24, 2017, p. 267-83. Disponivel em https://bit.ly/37GiRZQ. Acesso em 8/12/2020.

WARNER, Michael. Publics and Counterpublics. New York: Zone Books, 2005.

WARNER, Michael. Publics and Counterpublics with Michael Warner - Conversations with History. University of California Television, 7/5/2018. 53 min. Entrevista concedida a Harry Kreisler. Disponível em https://bit. ly/3mx987W. Acesso em 14/10/2020. 